\title{
Fractographic Analysis of Strontium-Modified Al-Si Alloys
}

Iryna Hren, Jaroslava Svobodova

Faculty of Mechanical Engineering, J. E. Purkyne University in Usti nad Labem. Pasteurova 3334/7, 40001 Usti nad Labem. Czech Republic. E-mail: iryna.hren@ujep.cz, jaroslava.svobodova

The research described in this contribution is focuses on fractographic analysis of the fracture area of $\mathrm{AlSi7Mg0.3}$ alloy with modified strontium. Modification is an effective tool for improving the mechanical properties of aluminum alloys and affecting the microstructure of the material. The aim of the paper is to revise the microstructure of the modified AISi7Mg0.3 alloy and to determine its strength properties. Within the experiment, the character of the refraction was evaluated and the presence of foreign particles and elements in the material fracture was monitored. Optical microscopy identified structural parameters of the castings just below the fracture surface as well as the course of the fracture line. Using a scanning electron microscope, the fracture area of the sample was analyzed, the EDS analysis was performed and the results of these analyzes were evaluated. An increased number of $\mathrm{O}, \mathrm{C}$ and $\mathrm{F}$ elements occurred on the surface of the samples. The occurrence of these elements most likely results in a material breakage, which also confirms the results achieved by the static tensile test. On the basis of the obtained results from the analyzes carried out, the mechanisms of the breach were determined.

Keywords: AlSi7Mg0.3, modification, strontium, beryllium, microstructure.

\section{Introduction}

Eutectic modification is a widely used process performed on aluminum and silicon alloys in particular for improving mechanical properties, in particular improving tensile strength, as well as for refining the structure of the brittle eutectic silicon phase. One of the most used modifiers is strontium. It is well known that the strontium additives to the aluminum alloy and silicon subelectal alloys result in the conversion of the eutectic morphology of silicon from the coarse plate structure to the lamellar structure [1]. Typical examples of microstructure of unmodified and Sr-modified alloys are shown in Fig. 1. Other elements, including sodium and several rare earth elements, are known to have different degrees of modification [2]. Strontium is less modifiable than sodium, but is far less reactive, therefore it provides a much longer modifying effect in high and stable use. It is most commonly introduced into the melt in the form of aluminum alloy (Sr containing usually $3.5 \div 10 \%$, rarely using pre-alloys with $\mathrm{Sr}$ content of up to $90 \%$ for low-melting alloys, as strontium dissolves with lower melting temperature, long before the conventional master alloy has reached the required $\mathrm{Sr}$ content in the melt). The alloys contain strontium in the particulate form of $\mathrm{SrAl}_{4}$ whichis in the melt disintegrate and react with silicon to form $\mathrm{Al}_{2} \mathrm{Si}_{2} \mathrm{Sr}$. This compound decomposes and releases $\mathrm{Sr}$ in pure form, which, according to the theory of surfaceactive modifiers, modifies the structure of eutectic silicon into the favorable shape of the thin tubes $[4,7]$. The onset of the modifying effect is significantly slower than that of sodium preparations. For acceleration, it is advantageous to move the melt (e.g., by induction stirring or occasional mechanical agitation). On the contrary, the sensation is very slow and becomes more oxidative than evaporation from the surface (as with sodium). Strontium is reported to have a sufficient modifying effect in the melt for 3 to 6 hours and partially resists the alloy even after re-melting (sometimes the ingots are already in the modified state using strontium). If addition of beryllium $(0.05 \div 0.2 \%)$ is added to the melt, the effect of the modification is extended to 10 hours $[5,6,12]$.

The addition of antimony thus induces the transformation of the eutectic silicon phase, where the silicon plates are transformed into lamellar morphology. It is generally known that the change in the silicon morphology that occurs with the modification is desirable. Unfortunately, the modification is also associated with negative side effects such as porosity, creep and disadvantageous casting surface morphology and is not always recommended [13]. In recent years, it has been found that the change in silicon morphology does not appear in isolation but is accompanied by a number of other significant changes in solidification and microstructure development. This paper compares the development of the cast structure at the macroscopic and microscopic scales of unmodified and modified alloys. The chosen modifier is strontium.

\section{Experiment}

This experiment is part of more extensive research on the study of structure and phase changes in the melt during Al-Si alloy casting with the addition of Sr modifiers and prolongation of its time effect using beryllium. In this part of the experiment, in the first stage, the aim was to dislodge the modifying effect of $\mathrm{Sr}$ at $5 \mathrm{~min}, 30 \mathrm{~min}, 1$ $\mathrm{h}$ and $2 \mathrm{~h}$ from the addition of $\mathrm{Sr}$ to the melt without the addition of beryllium, and in the second part of the experiment, the addition of $\mathrm{Sr}$ and $\mathrm{Be}$ into the melt. Experimental samples were cast in an interval of 1 hour up to 4 hours after addition of $\mathrm{Sr}$ and $\mathrm{Be}$.

In the next part of the experiment, strontium alloys, then strontium and beryllium, were prepared and evaluated, and the $\mathrm{Sr}$ and $\mathrm{Be}$ distribution in the structure was monitored by elemental EDS analysis on the TESCAN VEGA 3 electron scanning microscope. For the experiment, an AlSi7Mg0.3 alloy was added with a modifier $\mathrm{Sr}$ and AlBe5. This material contains $92.7 \%$ of aluminum, 
$7 \%$ of $\mathrm{Si}$ and about $0.3 \%$ of $\mathrm{Mg}$ (the chemical composition of the alloy according to CSN EN 1706 is given in Table 1). The next step was to add the modifier $\mathrm{Sr}$ and add $\mathrm{Be}$ to add to its efficiency. In this case $\mathrm{Sr}$ is used in the form of an AlSr10 master alloy with the addition of a modifier of $0.04 \%$. Beryllium is added as an AlBe5 alloy at a concentration of $0.20 \%$. In order to verify whether the modification was prolonged, samples were cast every hour for up to 4 hours after addition of $\mathrm{Sr}$ and $\mathrm{Be}$. The melting was carried out at $750-760^{\circ} \mathrm{C}$ by gravity casting into a preheated metal mold $\left(200^{\circ} \mathrm{C}\right)$. The experimental samples are poured out and then kept in the mold until they are cooled. The resulting castings were cylindrical with a diameter of about $19 \mathrm{~mm}$ and a length of about 210 $\mathrm{mm}$ and became the basis for subsequent microstructure analysis.

Tab. 1 The chemical composition of AlSi7Mg0.3 alloy (in weight) (ČSN EN 1706)

\begin{tabular}{|c|c|c|c|c|c|c|c|c|c|c|c|}
\hline $\mathrm{Si}$ & $\mathrm{Fe}$ & $\mathrm{Cu}$ & $\mathrm{Mn}$ & $\mathrm{Mg}$ & $\mathrm{Cr}$ & $\mathrm{Ni}$ & $\mathrm{Zn}$ & $\mathrm{Pb}$ & $\mathrm{Sn}$ & $\mathrm{Ti}$ & $\mathrm{Al}$ \\
\hline $6.5-7.5$ & $\leq 0.19$ & $\leq 0.05$ & $\leq 0.1$ & $0.25-0.45$ & - & - & $\leq 0.07$ & - & - & $\leq 0,25$ & residue \\
\hline
\end{tabular}

\subsection{Chemical composition of casting}

Spectral chemical analysis of the casting was carried out on the Q4 TASMAN optical emission spectrometer, which is designed for analysis of all metallic materials. Five castings were performed at sites near the quarry, from which the average value was determined for individual elements. The spectral analysis results are shown in Table 2. For all elements, the chemical composition corresponds to the desired AlSi7Mg0.3 alloy composition shown in Table 1. Spectral analysis did not detect the presence of the $\mathrm{Sr}$ and Be elements.

Tab. 2 The chemical composition of the casting (in weight)

\begin{tabular}{|c|c|c|c|c|c|c|c|c|c|}
\hline $\mathrm{Si}$ & $\mathrm{Fe}$ & $\mathrm{Cu}$ & $\mathrm{Mn}$ & $\mathrm{Mg}$ & $\mathrm{Cr}$ & $\mathrm{Zn}$ & $\mathrm{Pb}$ & $\mathrm{Ti}$ & $\mathrm{Al}$ \\
\hline 7.32 & 0.19 & 0.05 & 0.1 & 0.4 & - & - & - & - & residue \\
\hline
\end{tabular}

\subsection{Microscopic evaluation of structure and quality of modification - optical microscopy}

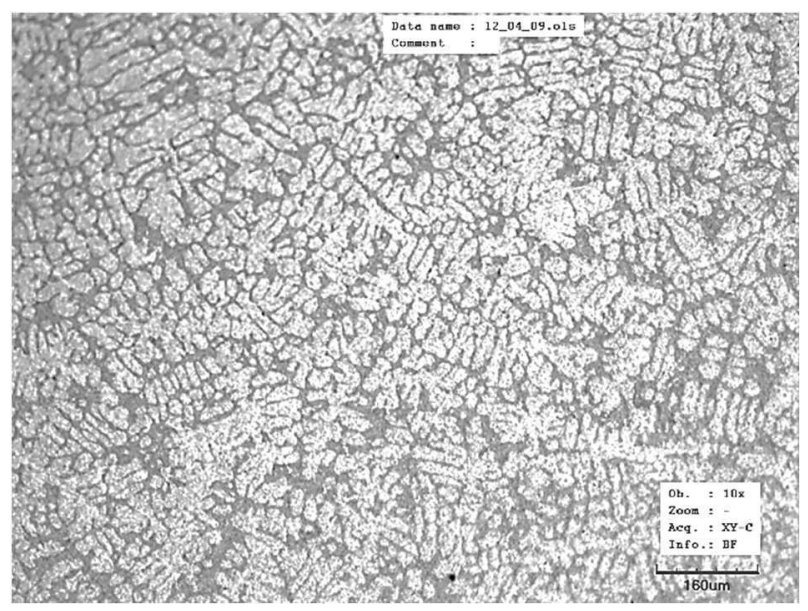

Fig. 1 Microstructure of alloy AlSi7Mg0.3

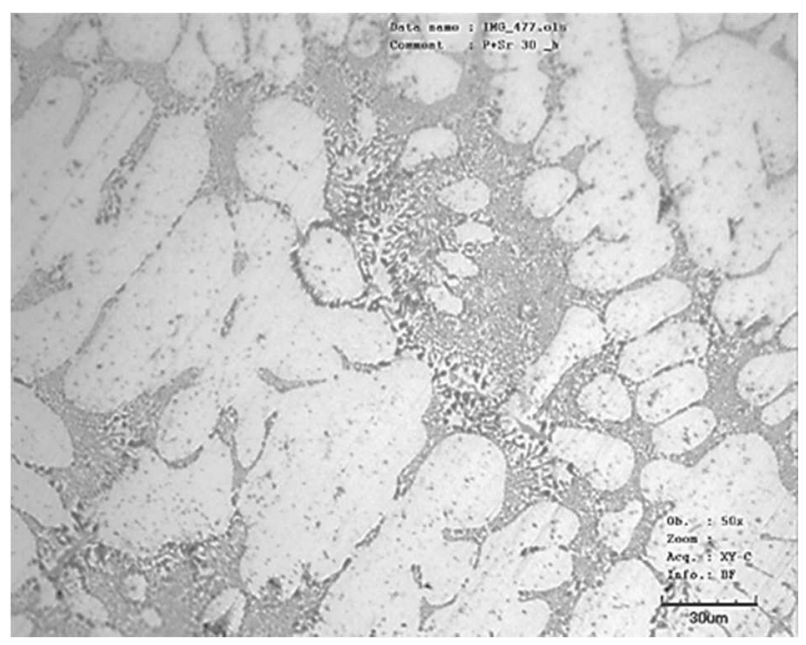

Fig. 2 Detail of the microstructure of the material under the fracture line AlSi $\mathrm{Mg} 0.3$

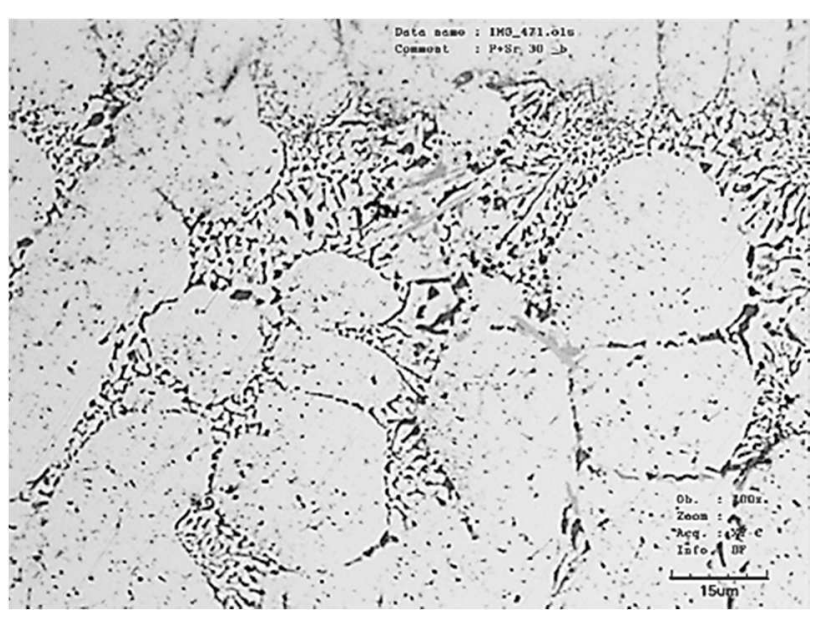

Fig. 3 Microstructure of alloy AlSi7Mg0.3 modified $\mathrm{Sr}$

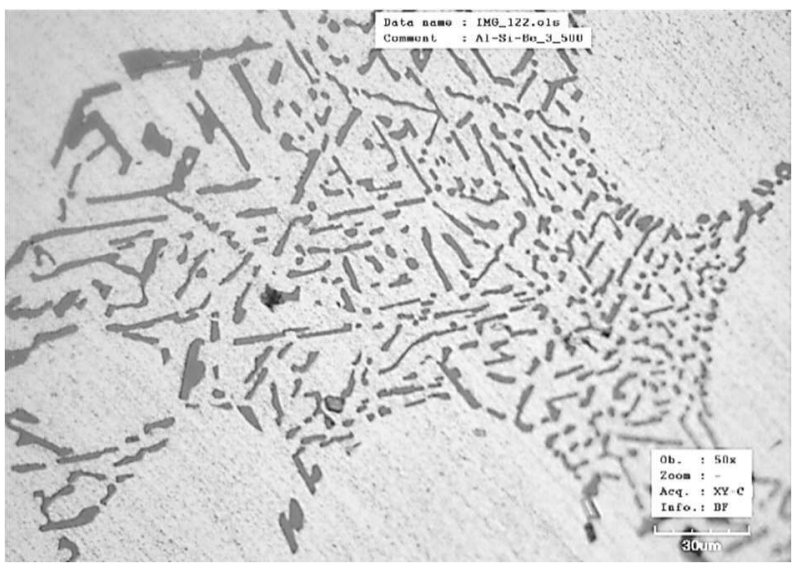

Fig. 4 The microstructure of the AlSi7Mg0.3 alloy with the addition of $\mathrm{Sr}$ and $\mathrm{Be}$

For examination of the microstructure of the samples was used a confocal laser microscope Olympus LEXT OLS 3100 . From the point of view of the overall structure 
evaluation in the region of the adjacent fracture it can be noted that this is eutectic silumin with a plurality of individual types of structural components. The basic components of the microstructure are $\alpha$ - solid solution and silicon in the form of finer and coarse hexagonal plates, which appear in the plane of the metallographic thin section appears as angular or partially rounded irregular needles of different sizes with a size in the range of 10 $40 \mu \mathrm{m}$ (Figure 1).

After the addition of strontium to the base material, the size of the needles of the eutectic silicon is increased, resulting in the expansion of the eutectic phase plates, and several thin plates are formed to form the long needle Si phases [8-11]. Thanks to the addition of beryllium, the modifying effect is prolonged. The morphology of eutectic silicon particles (rounded particles) is observable in all the samples examined. Together with the modifier, the needles of the eutectic silicon thickened and the distance between them was reduced (Figure 3 and Figure 4). The morphology of eutectic silicon particles is observable in all the samples examined. The microstructure of the fracture line in the fracture area is fractured (Figure 5). Secondary cracks are visible as well as internal (Figure $6)$.

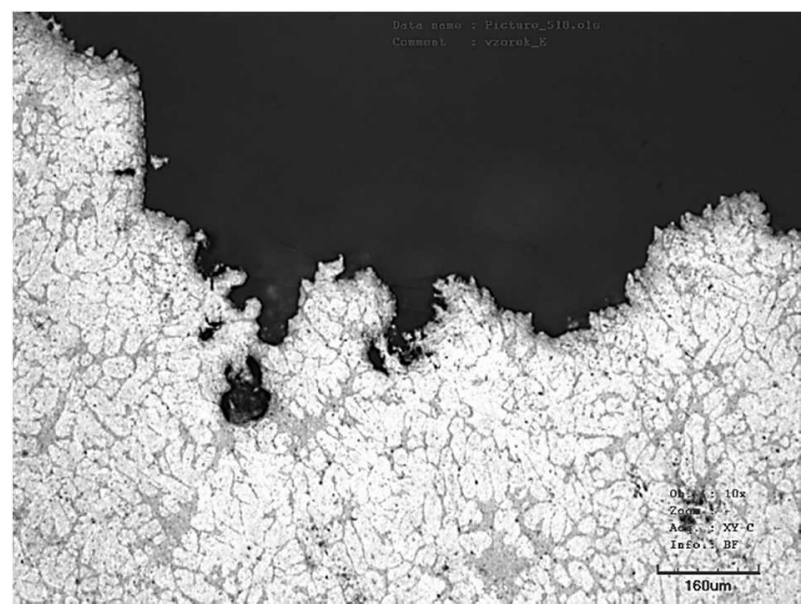

Fig. 5 Refractive area with a fission break

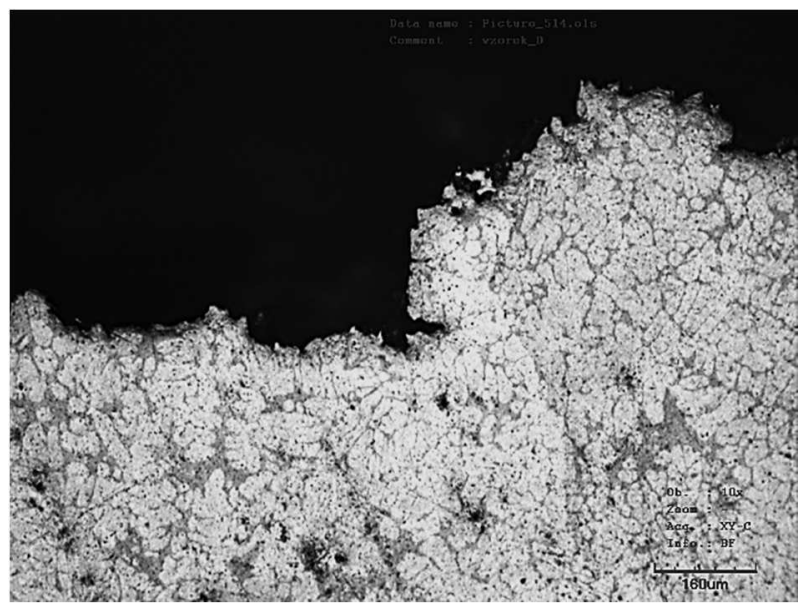

Fig. 6 Refractive area with a fission break

The major crack profile reflects the morphology of the primary dendritic structure. The major crack exceeded the two-phase areas ( $\alpha$-solid solution + silicon) and separeted the dendrite of $\alpha$-solid solution (Figure 7). Cracks of the deformed $\alpha$-solid solution are visible in Fig. 8. Secondary cracks are visible in the eutectic zones.

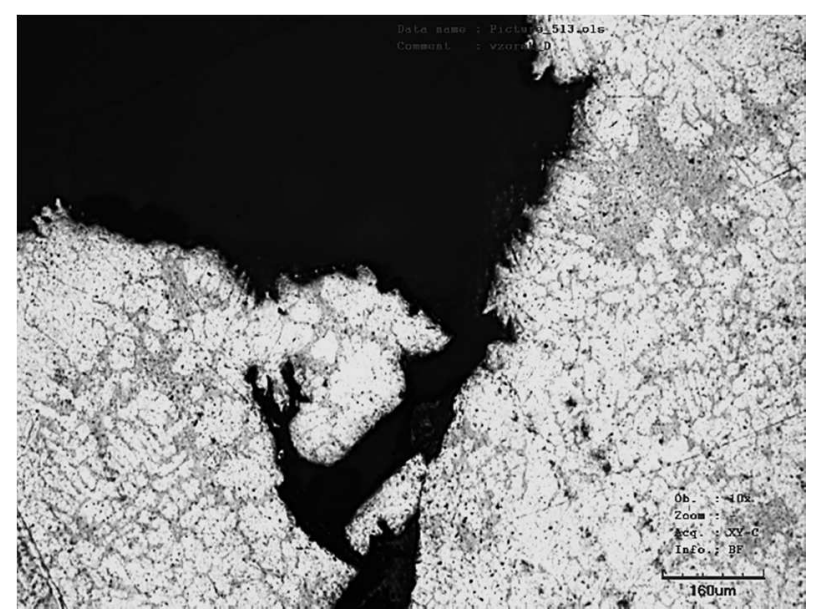

Fig. 7 Refractive area with a fission break

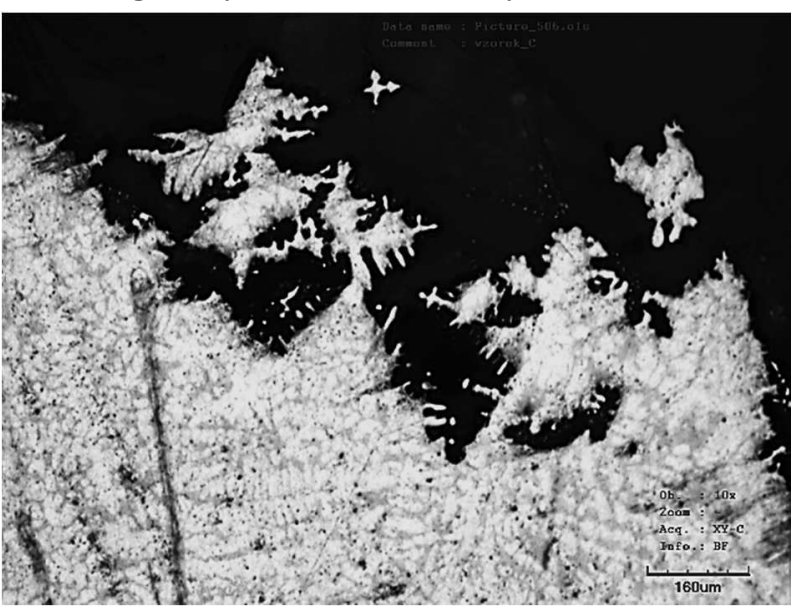

Fig. 8 Refractive area with a fission break

\subsection{SEM and EDS structure evaluation and fracto-} graphic analysis - electron microscopy

- Analyzed area №. 1

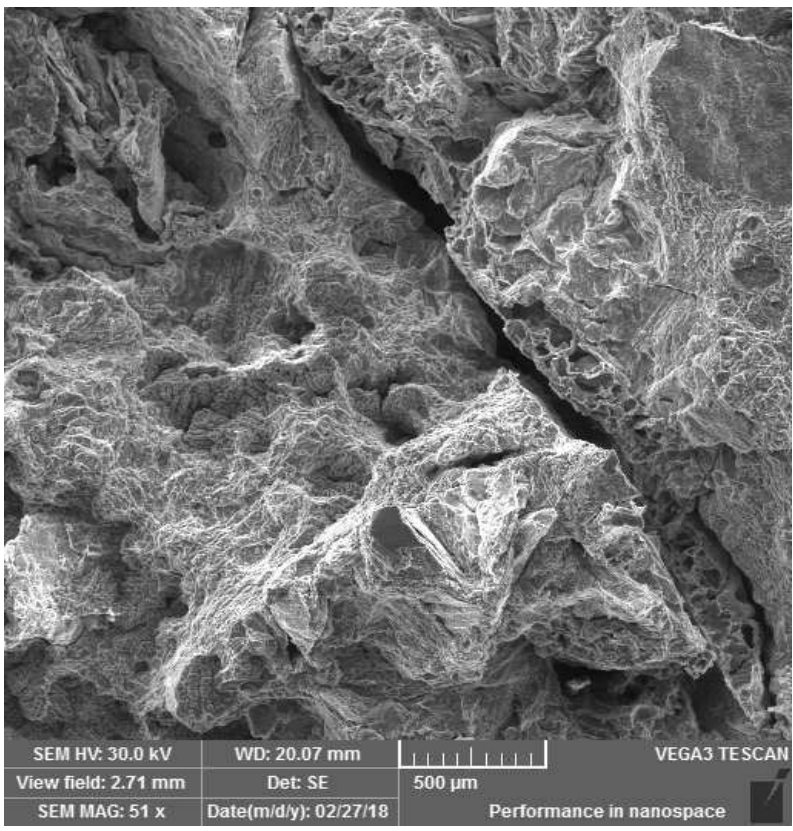

Fig. 9 SEM analysis - Fission intercrystalline fracture 
Tab.3 EDS analysis

\begin{tabular}{|c|c|c|c|c|c|}
\hline $\begin{array}{l}\overrightarrow{0} \\
\stackrel{\overrightarrow{0}}{0}\end{array}$ & $\stackrel{\mathscr{e}}{\mathscr{\omega}}$ & $\begin{array}{l}u \\
\dot{\Xi} \\
\dot{\Xi}\end{array}$ & 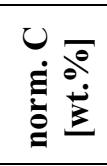 & 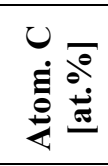 & 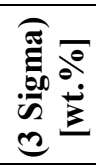 \\
\hline Al & K-series & 46.31 & 54.12 & 41.95 & 7.14 \\
\hline $\mathbf{C}$ & K-series & 15.10 & 17.65 & 30.73 & 16.89 \\
\hline $\mathbf{S i}$ & K-series & 13.79 & 16.11 & 12.00 & 2.21 \\
\hline $\mathbf{O}$ & K-series & 9.35 & 10.93 & 14.29 & 8.61 \\
\hline Mg & K-series & 1.02 & 1.20 & 1.03 & 0.32 \\
\hline Total: & & 68.61 & 100.00 & 100.00 & \\
\hline
\end{tabular}

In Fig. 9 is predominantly an interdendritic disruption of the test specimen. In the detailed view of the fracture area, it is possible to distinguish areas characterized by a characteristic fault with the evident fissionable violation. EDS analysis in this area shown the presence of $\mathrm{O}$ and $\mathrm{C}$ in large quantities, which caused total brekage and crack propagation across the entire cross section of the casting.

- $\quad$ Analyzed area №. 2

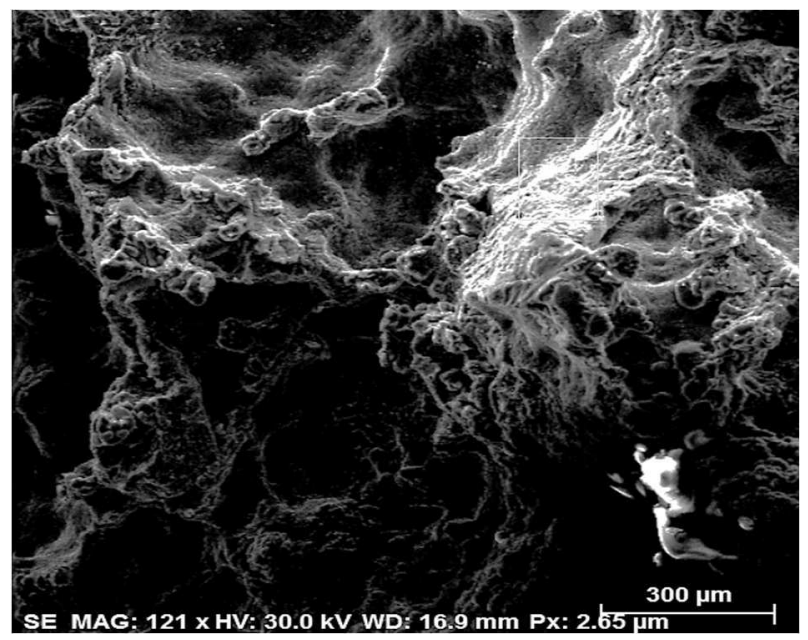

Fig. 10 EDS surface analysis

Tab.4 EDS analysis

\begin{tabular}{|c|c|c|c|c|c|}
\hline 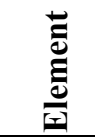 & 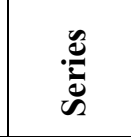 & 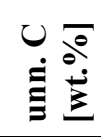 & 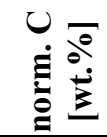 & 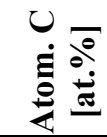 & 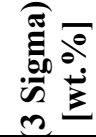 \\
\hline Al & K-series & 44.50 & 64.86 & 52.92 & 6.84 \\
\hline $\mathrm{C}$ & K-series & 9.09 & 13.25 & 24.28 & 11.51 \\
\hline $\mathbf{O}$ & K-series & 6.49 & 9.46 & 13.02 & 6.24 \\
\hline $\mathbf{S i}$ & K-series & 8.26 & 12.03 & 9.43 & 1.40 \\
\hline Mg & K-series & 0.27 & 0.40 & 0.36 & 0.16 \\
\hline Total: & & 68.61 & 100.00 & 100.00 & \\
\hline
\end{tabular}

Figure 10 shows a predominantly interdentritic disruption of the test specimen. Detailed view of the fracture area, it is possible to distinguish the areas characterized by a characteristic violation and the exposed dendrite on the fracture surface. EDS analysis of light fragments of the fracture break on the fracture surface shows the presence of $\mathrm{O}$ and $\mathrm{C}$ in large quantities. As a result of the high content of these elements is the total violation and the spread of cracks through the entire cross-section of the casting.
- Analyzed area №. 3

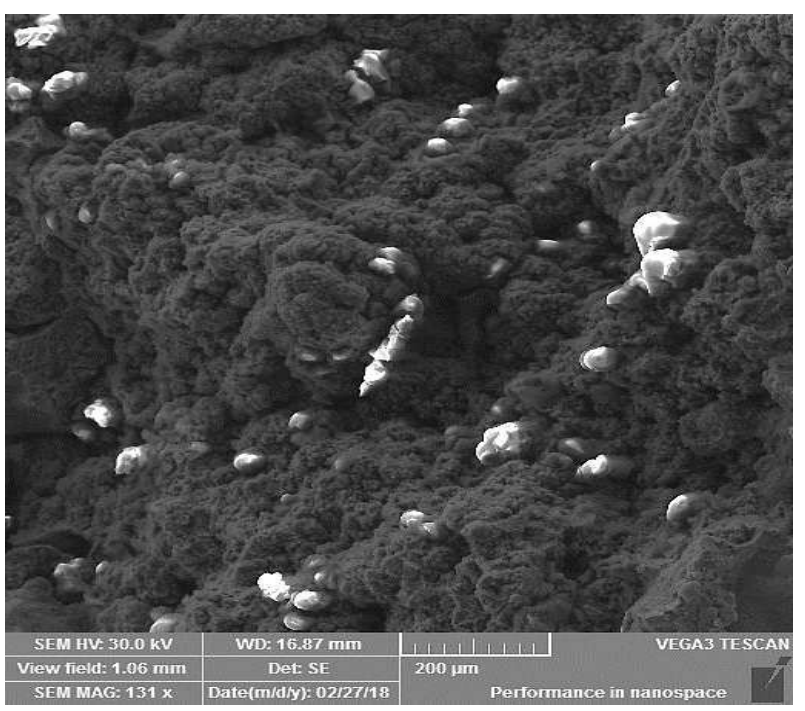

Fig. 12 SEM analysis - light spherical particles - oxides and exposed dendrites on the fracture surface

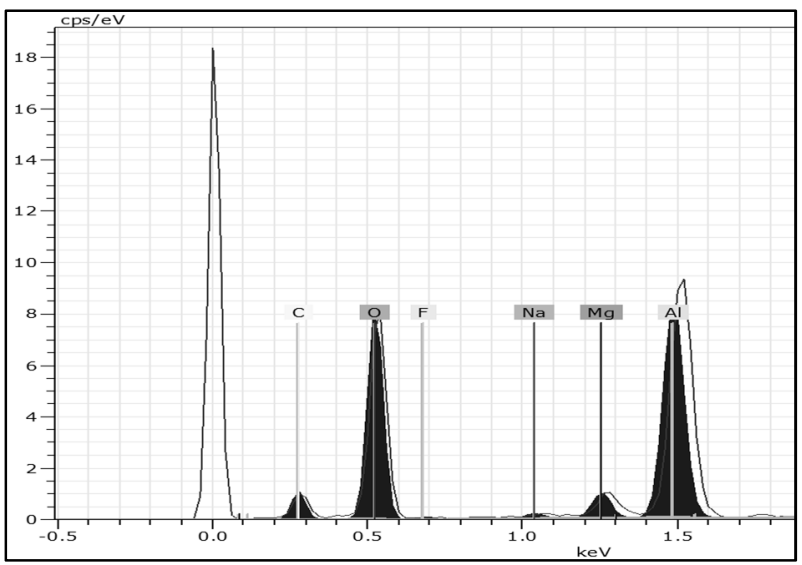

Fig. 13 Spectrum of analyzed chemical elements of the area EDS analysis (area in Figure 12

Tab.5 EDS analysis

\begin{tabular}{|c|c|c|c|c|c|}
\hline 氖 & 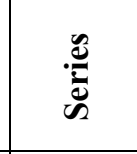 & 家 & 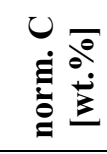 & 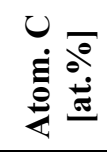 & 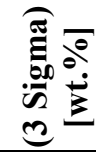 \\
\hline $\mathbf{O}$ & K-series & 16.50 & 61.85 & 62.70 & 53.20 \\
\hline Al & K-series & 29.01 & 15.40 & 9.26 & 4.68 \\
\hline Mg & K-series & 4.20 & 2.23 & 1.49 & 1.05 \\
\hline $\mathbf{F}$ & K-series & 2.57 & 1.36 & 1.16 & 4.76 \\
\hline $\mathbf{N a}$ & K-series & 1.40 & 0.74 & 0.52 & 0.62 \\
\hline $\mathrm{C}$ & K-series & 34.68 & 18.41 & 24.87 & 26.26 \\
\hline Total: & & 88.36 & 100.00 & 100.00 & \\
\hline
\end{tabular}

The analyzed area in Fig. 12 shows predominantly interdentritic failure of the test specimen. . In the detail view on the fracture surface can distinguish the area with the appearance of a bright spherical particles (oxides) and it is possible to observe the exposed dendritic cells. The surface EDS analysis on the fracture area identified the presence of $\mathrm{O}, \mathrm{C}$ and $\mathrm{F}$ where, in terms of the stoichiometric ratio, it can be deduced that the oxides and residues of the refining salt are present. The amount of unwanted ele- 
ments are reflected in large quantities, resulting in the formation and spread of fracture. A spherical rounding of particles containing $\mathrm{O}$ at the surface of the fracture was documented on the analyzed area from the bottom of the casting, which also caused the violation of the test specimen.

- $\quad$ Analyzed area №. 4

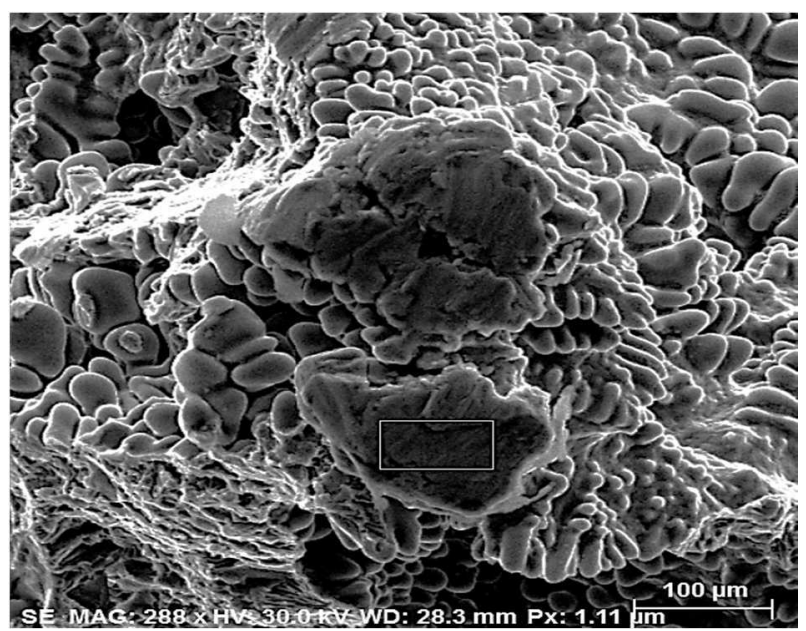

Fig. 14 SEM analysis - exposed dendrites on the fracture surface

In Fig. 14, exposed dendritic cells and interdendritic porosity can be observed. The surface EDS analysis of light fragments of the fracture break on the fracture surface shows the presence of O (5.99 wt.\%) and C (24.24 wt.\%), where in theterms of stoichiometric ratio can be said that it is the presence of the oxide membrane on the surface of the smooth flat plate caused a total breakage of the casting.

- Analyzed area №. 5

Fig. 15 documents predominantly interdendritic failure of the test bar. In the detailed view of the fracture area, areas with a characteristic morphology break can be distinguished. In the middle part of the cast surface, spherical particles containing O (59.45 wt.\%) on the surface of the fracture can be seen, which also contributed to crack propagation and subsequent fracture.

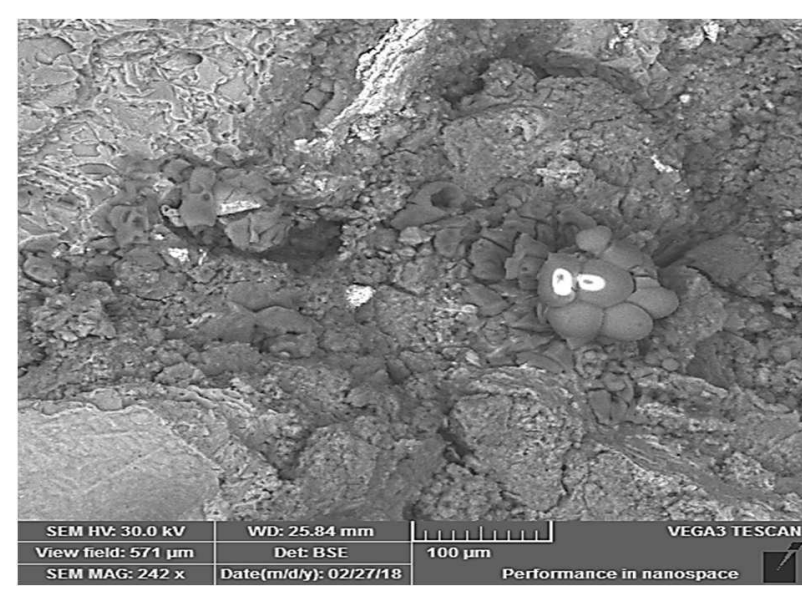

Fig. 15 SEM analysis - interdendritic violation, ductile violation with hole morpholog

\subsection{Static tensile test}

In the second part of the experiment AlSi7Mg0.3 alloys were cast and then tested specimens (according to CSN EN ISO 4287) in 5 variations: samples №. 1 are free of strontium and beryllium, samples №. 2 contain $0.04 \%$ Sr and $0.1 \%$ Be, samples №. 3 contains $0.04 \% \mathrm{Sr}$ and $0.15 \% \mathrm{Be}$, and samples №. 4 contains $0.04 \% \mathrm{Sr}$ and $0.2 \%$ Be. The test samples were subjected to a static tensile test on a universal tearing machine $100 \mathrm{kN}$ Hegewald \& Peschke. The results of the static tensile test including the average strength and ductility are shown in Table 6.

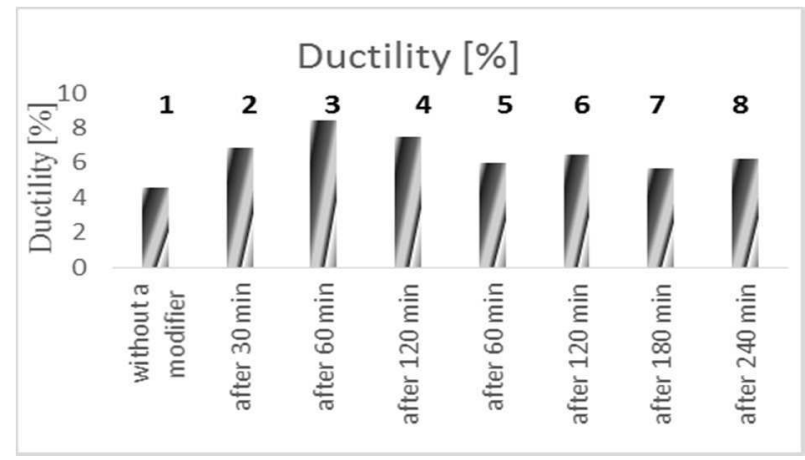

Fig. 16 Comparison of ductility of all materials

1) $\mathrm{AlSi} 7 \mathrm{Mg} 0.3$; 2) $\mathrm{AlSi} 7 \mathrm{Mg} 0.3+\mathrm{Sr}(0.04 \%)$; 3) AlSi7Mg0.3 + Sr (0.04\%); 4) AlSi7Mg0.3 + Sr (0.04\%); 5) $\mathrm{AlSi} 7 \mathrm{MgO} 0.3+\mathrm{Sr}(0.04 \%)+\mathrm{Be}(0.15)$; 6) AlSi $7 \mathrm{Mg} 0.3$ $+\operatorname{Sr}(0.04 \%)+B e(0.15) ; 7) \mathrm{AlSi} 7 \mathrm{Mg} 0.3+\mathrm{Sr}(0.04 \%)$

$+B e(0.15 ; 8)$ AlSi7Mg0.3 + Sr $(0.04 \%)+B e(0.15)$

Tab. 6 Strength and elongation results

\begin{tabular}{|c|c|c|c|c|c|c|c|c|c|c|c|}
\hline 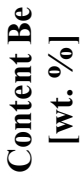 & 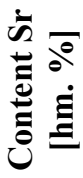 & & 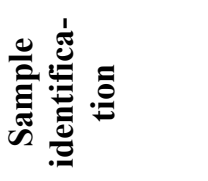 & \multicolumn{3}{|c|}{ 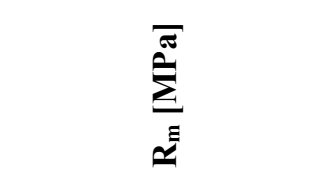 } & 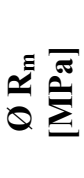 & \multicolumn{3}{|c|}{$\frac{\sqrt{e}}{4}$} & $\frac{e^{0}}{a}$ \\
\hline 0.00 & 0.00 & $\mathbf{A}$ & & 131 & 151 & 50 & 110 & 6.2 & 5.4 & 2.2 & 4.60 \\
\hline 0.00 & 0.04 & B & After 30 min & 149 & 165 & 164 & 159 & 7.3 & 6.9 & 6.3 & 6.83 \\
\hline 0.00 & 0.04 & B1 & After 1 hr & 151 & 153 & 146 & 150 & 7.8 & 7.9 & 9.5 & 8.40 \\
\hline 0.00 & 0.04 & B2 & After 2 hr & 146 & 150 & 154 & 150 & 7.5 & 6.8 & 8.2 & 7.50 \\
\hline 0.15 & 0.04 & $\mathbf{C}$ & After 1 hr & 123 & 167 & 81 & 123 & 5.6 & 9.2 & 3.1 & 5.96 \\
\hline 0.15 & 0.04 & D & After 2 hr & 138 & 168 & 96 & 134 & 4.7 & 11.3 & 3.5 & 6.50 \\
\hline 0.15 & 0.04 & $\mathbf{E}$ & After 3 hr & 131 & 137 & 123 & 130 & 5.7 & 6.5 & 4.9 & 5.70 \\
\hline 0.15 & 0.04 & $\mathbf{F}$ & After 4 hr & 152 & 166 & 146 & 154 & 6.2 & 6.8 & 5.7 & 6.23 \\
\hline
\end{tabular}


Samples A, C, D revealed residuals of the refining salt and the presence of oxides, resulting in a significant decrease in tensile strength: e.g. A - $50 \mathrm{Rm}$, which is $30 \%$ $\mathrm{Rm}$; e.g. C - $81 \mathrm{Rm}$, which is $60 \% \mathrm{Rm}$; e.g. D - $96 \mathrm{Rm}$, which is $65 \% \mathrm{Rm}$ of elongation versus experimental samples B, B1, B2, E, F (Table 6).

\section{Conclusion}

In the framework of the experiment was carried out spectral chemical analysis of the casting, SEM and EDS analysis in the area of the quarry and was carried out static tensile test. The surface EDS analysis shows the presence of $\mathrm{O}$ and $\mathrm{C}$ in large amounts (up to $15 \%$ ) of the desired composition in the fracture area, which is inadmissible in view of its negative influence on the mechanical and chemical properties of the alloy. In the microstructure of the cast alloy, beryllium and strontium were identified on the needles of eutectic silicon, with the beryllium being coupled to the strontium, thereby prolonging the modification time. Beryllium has also been found to be evenly spread in the solid solution between dendritic cells, presumably preventing the breakdown of $\mathrm{SrAl}_{4}$, thereby prolonging the strontium disintegration time. Samples A, C, D showed lower tensile strengths and lower ductility compared to samples B, B1, B2, E, F. Cause of this is formation of cracks on the surface of test specimens.

In the detailed view of the fracture area, it is possible to distinguish areas characterized by fission intercrystalline breakage with the presence of exposed dendrites, but also by ductile morphology breakage. In the fracture area, a combination of ductile and fissile distortion can be observed. EDS analysis of the bright area fission breach at the fracture area shows the presence of $\mathrm{O}$ and $\mathrm{C}$ in large amounts, which contribute to the overall breakage and spreading of the crack. It has been found that test specimens remain residues of the refining salt and oxidative membranes are formed. Due to this finding, we can say that there was insufficient cleaning of the melt before casting. In the microstructure, spherical particles containing $\mathrm{O}$ are present on the surface of the fracture of the casting. These oxidic particles also have an influence on the fracture of the material. From all the analyzes and fractographic analyzes carried out, it can be stated that the initiator of crack insertion and subsequent cracking of the cast under load is a large amount of $\mathrm{O}$ and $\mathrm{C}$, causing total cracking and crack propagation across the entire cross section of the cast.

\section{Acknowledgements}

This contribution came from support of project $S G$ 4820715 2014-48 01 at UJEP.

\section{References}

[1] MICHNA, Š. a kol. (2005). Encyklopedie hliníku, 1. Vydání, Prešov, SR: Adin s. r. o.
[2] BOliBRUChOVÁ, D., TILlOVÁ, E. (2005). Zlievarenské zliatiny Al-Si. Žilina: EDIS - vydavatel'stvo ŽU.

[3] MONDOLFO L. F. (1979). Aluminium Alloys, Structure and Properties. Butterworths, London.

[4] DAVIDSON, C. J., et al (2002). The Effect of solution heat Treatment Time on Fatigue Properties of an Al-Si-Mg Casting Alloy. FFEMS, Vol. 25, pp .223-230.

[5] TIllova, E., CHALUPOVA, M., HURTAlOVA, L., DURINIKOVA, E. (2011). Quality Control of Microstructure in Recycled AlSi Cast Alloys. Manufacturing Technology, Vol. 11, No. 11, pp. 70-76.

[6] NÁPRSTKOVÁ, N., CAIS, J., SVOBODOVÁ, J. (2013). The Effect of Modification by Strontium of the AlSi7Mg0.3 Alloy on the Surface Roughness. Manufacturing Technology, Vol. 13, No. 3, pp. 380-384.

[7] MICHNA, Š., NAPRSTKOVÁ, N., LUKÁČ, I. (2011). Mechanical Properties Optimization of AlSi12CuMgNi Alloy by Heat Treatment. $\mathrm{Me}$ tallofizika i Noveishie Teknologii, Vol. 11.

[8] LIPIŃSKI, T. (2011). Microstructure and Mechanical Properties of the AlSi13Mg1CuNi Alloy with Ecological Modifier. Manufacturing Technology, Vol.11, No.11, pp.40-44.

[9] HONZÁTKO, R., MICHNA, Š., CAIS, J. (2013). The Influence of Porosity on Mechanical Propertis of Casts Produced from Al-Si Alloys. Manufacturing Technology, Vol.13, No 3.

[10] MICHNA, Š., LUKÁČ, I. (2012). Praktická fraktografie. Univerzita J. E. Purkyně v Ústí nad Labem, OPTYS, spol. s r. o., 237 p.

[11] NÁPRSTKOVÁ, N., CAIS, J., SVOBODOVÁ, J. (2013). The Effect of Modification by Strontium of the AlSi7Mg0.3 Alloy on the Surface Roughness. Manufacturing Technology. October 2013, Vol. 13, No. 3, pp. 380-384.

[12] CAIS, J., SVOBODOVA, J., STANCEKOVA, D. (2017). Modification of the AlSi7Mg0.3 alloy using antimony. Manufacturing Technology. Vol. 17, pp. 685-690.

[13] VOREL, I., JENÍČEK, Š., KÁŃA, J., IBRAHIM, K., KOTĚSOVEC, V. (2016). Use of Optical and Electron Microscopy in Evaluating Optimization by Material-Technological Modelling of Manufacturing Processes Involving Cooling of Forgings. Manufacturing Technology. Vol. 16, No.6, pp. 1383-1387.

10.21062/ujep/198.2018/a/1213-2489/MT/18/6/900

Copyright (C) 2018. Published by Manufacturing Technology. All rights reserved. 